\title{
Article \\ Comparative Study of the Field Performances of Pressure-Grouted Micropiles Using Gravity and Packers
}

\author{
Ong Heo ${ }^{1}$, Yeowon Yoon ${ }^{2}$ and Jinung Do ${ }^{3, *}$ \\ 1 Civil Business Center, DODAM E\&C, Incheon 21558, Korea; ong1126@dodamenc.co.kr \\ 2 Department of Civil Engineering, Inha University, Incheon 22212, Korea; yoonyw@inha.ac.kr \\ 3 Department of Ocean Civil Engineering, Gyeongsang National University, Tongyeong 53064, Korea \\ * Correspondence: jinung@gnu.ac.kr
}

Citation: Heo, O.; Yoon, Y.; Do, J.

Comparative Study of the Field Performances of Pressure-Grouted Micropiles Using Gravity and Packers. Appl. Sci. 2021, 11, 6736. https://doi.org/10.3390/app11156736

Academic Editor: Luca Susmel

Received: 8 July 2021

Accepted: 21 July 2021

Published: 22 July 2021

Publisher's Note: MDPI stays neutral with regard to jurisdictional claims in published maps and institutional affiliations.

Copyright: (c) 2021 by the authors. Licensee MDPI, Basel, Switzerland. This article is an open access article distributed under the terms and conditions of the Creative Commons Attribution (CC BY) license (https:// creativecommons.org/licenses/by/ $4.0 /)$.

\begin{abstract}
When underground space requires excavation in areas below the water table, the foundation system suffers from buoyancy, which leads to the uplifting of the superstructure. A deep foundation system can be used; however, in cases where a hard layer is encountered, high driving forces and corresponding noises cause civil complaints in urban areas. Micropiles can be an effective alternative option, due to their high performance despite a short installation depth. Pressurized grouting is used with a packer to induce higher interfacial properties between micropile and soil. In this study, the field performance of micropiles installed using gravitational grouting or pressure-grouted using either a geotextile packer or rubber packer was comparatively evaluated by tension and creep tests. Micropiles were installed using pressure grouting in weak and fractured zones. As results, the pressure-grouted micropiles showed more stable and stronger behaviors than ones installed using the gravitational grouting. Moreover, the pressure-grouted micropile installed using the rubber packer showed better performance than the one using the geotextile packer.
\end{abstract}

Keywords: pressure-grouted micropiles; gravitational grouting; geotextile packer; rubber packer; tension load test; creep test

\section{Introduction}

Groundwater tables adjacent to water bodies such as rivers, estuaries, and near the shore affect underground construction, and countermeasures against groundwater flows are necessary. Steel sheet piling, slurry trench walls, cast-in-place pile, soil-cement wall, etc., are widely used to cut off the groundwater table, and then a working space is excavated within the cutoff walls [1]. A seepage is induced into the working space due to the head differential. Although cutoff walls are installed into bedrock, the walls do not ensure perfect prevention of water intrusion into the working space due to the uncertainty of cutoff walls [2]. Therefore, a foundation system is constructed while working space is temporarily ensured by pumping water out (Figure 1a). After the completion of sub- and super-structure construction, the pump is removed, and excavated space is backfilled. The groundwater table rises until the equilibrium state is reached, and the system is subjected to buoyancy and uplifting force. This process finally results in the tensile force of the foundation system [3] (Figure 1b). The pullout capacity of a pile is dependent on the length of the pile and interfacial bonding capacity between pile and ground [4]. When a hard layer or bedrock exists, a deep foundation system has various limitations. For example, in the case of a bored pile, it is difficult to assure the design length of the pile with deep penetration due to the high penetration resistance of the hard layer. For a driven pile, noise during construction causes civil complaints [5].

In this situation, a micropile can be an effective alternative to the deep foundation system. A micropile has a small diameter (typically less than $300 \mathrm{~mm}$ ) consisting of a reinforcing bar and grouting [6]. The micropile is classified as a non-displacement pile because of its small diameter and boring installation method [7]. A steel bar is inserted into 
a borehole, and the borehole is grouted, bonding the reinforcing bar and surrounding soils. The bonding strength between micropile and soil differ according to the types of grouting (e.g., level of pressure during grouting). Due to grouting, the unit bearing and pullout capacity of the micropile are considerably higher than those of conventional piles [8,9].

(a)

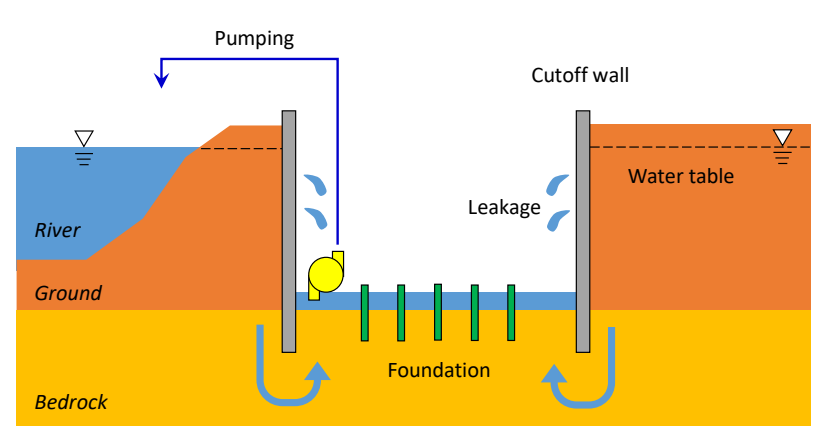

(b)

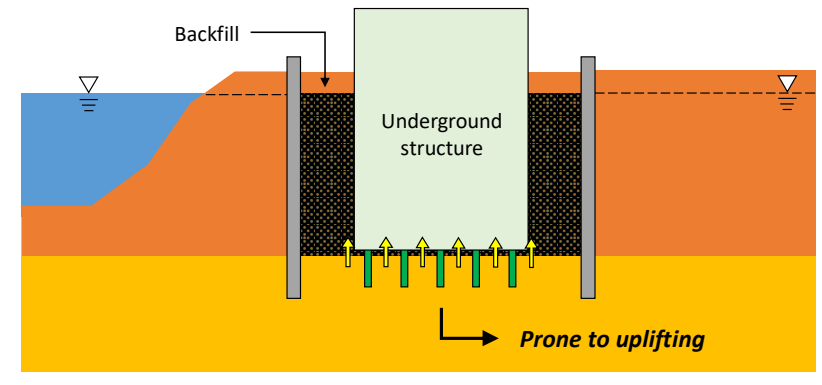

Figure 1. Uplifting mechanism of foundation systems adjacent to a river channel. (a) Underground construction inducing seepage into the construction space, and (b) buoyancy of the structure is induced after backfilling due to recovery of ground water. This mechanism causes an uplifting force to act on the foundations.

The unit price of a micropile is much lower than for conventional systems, as relatively small-scale equipment is used during micropile construction. For example, using 2017 market prices in South Korea (based on a personal communication from an engineering company in South Korea), the rental fee for construction equipment is approximately USD 90,000 per month for cast-in-place pile construction (e.g., drilling machine, crane, oscillator, casing, power pack, and water supply truck), while USD 26,000 is required for micropile construction (e.g., crawler drill, air compressor, grouting mixer, crane, water supply truck, pork lift, and generator). Therefore, a micropile is an attractive alternative where bedrock exists at shallow depth and the foundation system is subjected to the uplifting force due to groundwater.

To install a micropile, a centralizer and a reinforcing bar are inserted into a borehole, and cement grout is poured into the borehole through a tremie pipe. At this stage, the micropile is classified into four types (Type $A, B, C$, and $D$ ) according to the filling methods of the cement grout as presented by Pearlman and Wolosick [10]. The simplest method is Type $A$, which uses gravitational grouting. The grouting is applied after boring with no pressure. The gravitational fill technique is generally used when the micropile is located on a rock or the design load is not significantly high [11]. For the Type $B$ method, gravitational grouting is first placed into the casing, and pressure grouting (typically at $1 \mathrm{MPa}$ ) is applied during the withdrawal of casing or auger. The Type $C$ method is similar to Type $B$, but pressure grouting greater than $1 \mathrm{MPa}$ is applied from the head of the reinforcing pipe. Both Types $B$ and $C$ increase the bonding between the grout and ground compared to Type $A$; however, higher pressure ( $>1 \mathrm{MPa}$ ) is difficult to apply because of the geotechnical uncertainties (e.g., potential hydro-fracturing of the ground or leakage along the casing, Table $1[12,13])$. To handle these issues, a Type $D$ method uses a packer to constrain the grouting and enhance the bonding process [14]. Primary grouting is first introduced into the borehole, and a high level of pressure (2-8 MPa) is applied with the presence of the packer. 
Table 1. Historical failures associated with micropiles.

\begin{tabular}{|c|c|c|c|c|}
\hline Year & Location & Features & Results & Reference \\
\hline 1996 & $\begin{array}{l}\text { Johnson, } \\
\text { Tennessee }\end{array}$ & $\begin{array}{l}\text { Irregular and poor rock layers } \\
\text { beneath soft to firm clay layers }\end{array}$ & $\begin{array}{l}\text { A ground surface was disturbed } \\
\text { significantly due to drilling. Accordingly, } \\
\text { soil softening and localized } \\
\text { subsidence occurred. }\end{array}$ & [12] \\
\hline 2004 & $\begin{array}{l}\text { Richmond-San } \\
\text { Rafael Bridge, CA }\end{array}$ & $\begin{array}{l}\text { High capacity micropile; Grout } \\
\text { thixotropy when the mix water, } \\
\text { ambient air, the extreme } \\
\text { temperature of bagged cement, etc. }\end{array}$ & $\begin{array}{l}\text { Failed to field test. Post grouting was } \\
\text { attempted twice, but failed due to rapid } \\
\text { strength gain with strong } \\
\text { lateral confinement. }\end{array}$ & [13] \\
\hline 2005 & $\begin{array}{l}\text { Knoxville, } \\
\text { Tennessee }\end{array}$ & $\begin{array}{l}\text { Battered micropiles, thick grout } \\
\text { mixture, poor quality control, } \\
\text { tight-fitting centralizers, etc. }\end{array}$ & $\begin{array}{l}\text { The central reinforcing bar failed to install } \\
\text { to the bottom of the drilled hole; therefore, } \\
\text { not passed the field tests. }\end{array}$ & [12] \\
\hline
\end{tabular}

Schleiss (1986) suggested that pressure grouting might be an effective countermeasure for a pervious tunnel with many fractures [15]. Kasper and Meschke (2006) observed that the maximum settlement of the crown of the tunnel was reduced as the pressure of the grouting was increased [16]. In addition, pressure-grouted soil nailing can be effectively applied to completely decomposed granite fill [17]. Therefore, the pressure grouted micropile is an attractive and reasonable option for overcoming irregularities and weaknesses in the fractured zone.

The packability of the packer is the key factor in determining the performance of the micropile. The packer is typically a sack-shaped geotextile consisting of expanded polytetrafluoroethylene (ePTFE). This packer is manually fixed at the desired location and tightened by wires. However, due to manual packing, grouting is susceptible to leaking from inside the borehole $[18,19]$. Moreover, during the boring of the hole, water and soils inside of the borehole are mixed, and a slime (slurry) is produced. The slime decreases the bonding stress between the reinforcing bar-grout-soils and increases the settlement of the foundation system $[20,21]$. It is almost impossible to address the slime problem using existing packers.

A newly devised rubber packer was introduced in this study to overcome the issues on the conventional packer [22]. The rubber packer can induce higher packability onto the borehole due to its flexibility of rubber than the geotextile packer. The rubber packer is possible to reuse after use. Moreover, the rubber packer has a nozzle that can drain the slime inside the borehole leading better capacity of micropiles.

Despite the importance of the packer's packability, the pressure-grouted micropile with packer is yet well-evaluated. Even research on the conventional (geotextile) packer are limited for micropile either lab or field. Therefore, in this study, tension load and creep tests were conducted to evaluate and compare the performance of micropiles installed by different methods, such as gravitational grouting and pressure grouting using geotextile and rubber packers.

\section{Test Site}

The test field is an alluvial plain of the Han River in Seoul, South Korea. This area can be classified as granitic rocks of the Precambrian period, and granites of the Mesozoic period. The results of the site investigation revealed that deposits at the site (Figure 2a) were landfill at the depths of 0-8 $\mathrm{m}$ (sandy silt, SM classified by ASTM D2487-17e1 [23]), a sedimentary layer at the depths of 8-16 m (Clay with low plasticity, CL), weathered rock at the depths of 16-21 m (poorly graded sand, $S P$ ), and a soft rock at the depths deeper than $21 \mathrm{~m}$. A standard penetration testing (SPT) showed average measured $N$-values ( $\left.N_{\text {measured }}\right)$ of 6.3 and 11.5 blows per $30 \mathrm{~cm}$ for the landfill and sedimentary layers, respectively. Details of the $N$-values are not shown, as the landfill and sedimentary layers were excavated and out of the research target. The weathered rock and soft rock layers showed high penetration resistances as $N_{\text {measured }}=50$ blows per $5-25 \mathrm{~cm}$. The rock quality designation (RQD) and 
total core recovery (TCR) of the soft rocky layer indicate that the rock quality of the layer is poor in general (average $\mathrm{RQD}=37 \%$ and $\mathrm{TCR}=83 \%$ ). Using a borehole image profile system (BIPS), the evidence of the fractured zone was identified with major and minor faults (Figure $2 b$ ). The fault zone and weak zone showed variable thicknesses from a shallow thickness (3-4 m) to a heavy thickness $(8-10 \mathrm{~m})$.

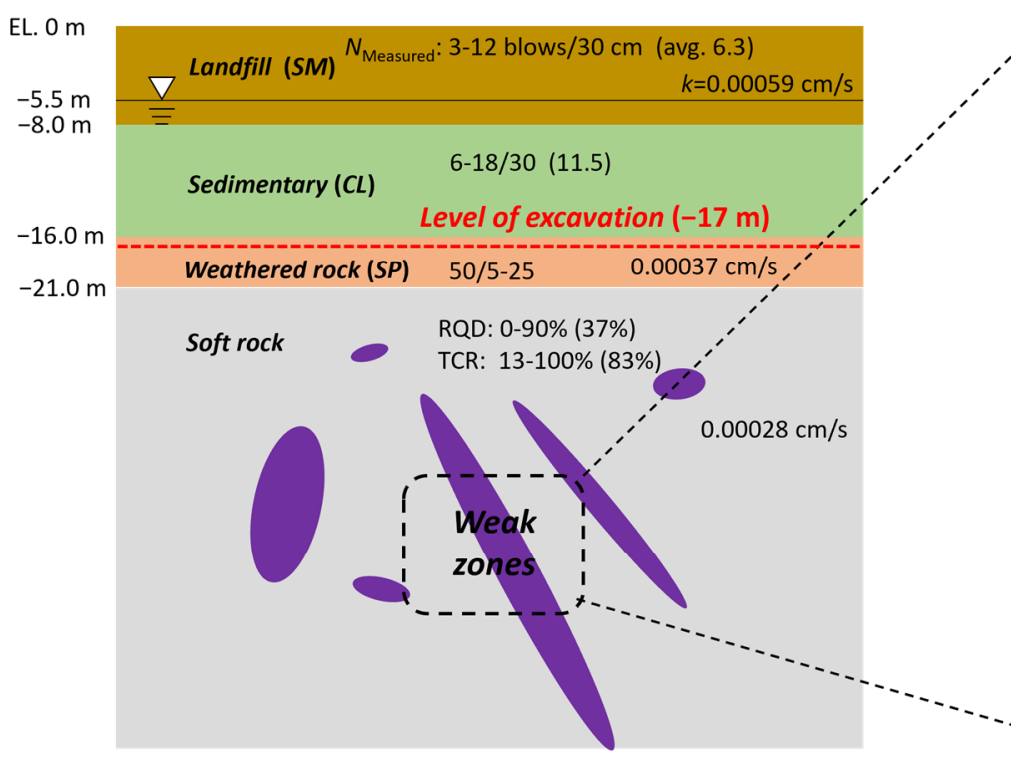

(a)
EL. $-23 \mathrm{~m}$

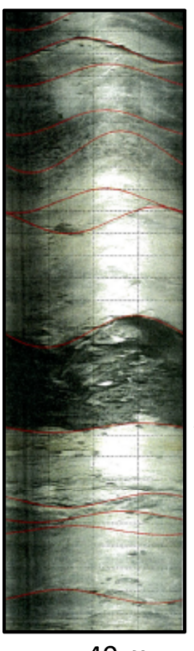

$-40 \mathrm{~m}$

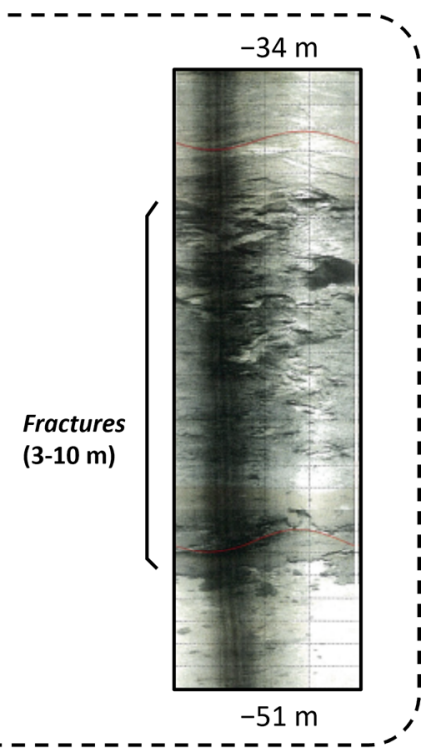

(b)

Figure 2. Profiles of the construction site. (a) Stratification of the site and (b) examples of fractures surveyed by BIPS (Note, $N_{\text {measured }}$ : measured $N$ value by SPT, $k$ : hydraulic conductivity of soils, RQD: rock quality designation, TCR: total core recovery, $S M$ : sandy silt, $C L$ : clay with low plasticity, and $S P$ : poorly graded sand).

The groundwater table exists at EL. $-5.5 \mathrm{~m}$. An excavation and cutoff walls were required for underground construction. The groundwater should be pumped during the construction. The construction site is a nearby urban area. A deep foundation system may cause construction difficulties and civil complaints. This situation exactly corresponds to those depicted in Figure 1. Therefore, micropiles were selected as the foundation system of the underground structure.

\section{Material and Test Program}

\subsection{Testing Material Properties and Installation of Micropiles}

The dimensions and properties of the borehole, grout, and reinforcing bar used in the installation of the micropiles are summarized in Table 2. Auxiliary components were used such as a casing (SS400, $\left.f_{y}: 400 \mathrm{MPa}, \mathrm{KS} \mathrm{D} 3503\right)$, a plate (SM490, $\left.f_{y}: 490 \mathrm{MPa}, \mathrm{KS} 2014\right)$, and a coupler and nut (Steel grade 500/550, $f_{y}: 500 \mathrm{MPa}, f_{u}: 550 \mathrm{MPa}$ ). Assuming a target load $(T L)=1000 \mathrm{kN}$ equivalent to a rock anchor [24], all design parameters satisfy the geotechnical and structural requirements provided by Sabatini et al. [14].

Three micropiles were installed using different grouting methods: (1) gravitational grouting; (2) pressurized grouting with a geotextile packer; and (3) pressurized grouting with a rubber packer. For the micropile with the gravitational grouting, a reinforcing bar was inserted into a borehole and the grouting was injected via gravity. For the pressuregrouted micropile with a geotextile packer, a geotextile packer was attached to a target position of the reinforcing bar and manually fixed with wires (Figure 3a). The reinforcing bar with the flat packer was inserted into a borehole, and the packer was filled with pressure grouting through the preinstalled small pipe and fitted at the borehole (Figure $3 \mathrm{~b}$ ). At this stage, the induced slime (i.e., the mixture of water, soil, and grout) moved to the upper part of the borehole when the grout was injected (Figure 3b). It was unavoidable 
that the slime remained at the upper part of the borehole. The impurity of the grouting by the slime impaired the interfacial stress of the grouting $[25,26]$.

Table 2. Material properties of micropiles.

\begin{tabular}{|c|c|c|c|}
\hline \multicolumn{2}{|c|}{ Property } & Value & Note \\
\hline Borehole & $\begin{array}{l}\text { Depth (or pile length) [m] } \\
\text { Diameter [mm] }\end{array}$ & $\begin{array}{l}10.5 \\
177\end{array}$ & $\begin{array}{c}L_{\mathrm{b}} \\
D_{\text {hole }}\end{array}$ \\
\hline Grout & $\begin{array}{c}\text { Type of cement } \\
\text { Area [mm²] } \\
\text { Water/cement [\%] } \\
\text { Elastic modulus [GPa] } \\
\text { Compressive strength [MPa] }\end{array}$ & $\begin{array}{c}\text { Portland cement } \\
20,187.9 \\
45 \\
29.9 \\
40\end{array}$ & $\begin{array}{c}\text { Borehole area-Micropile area; } A_{\mathrm{g}} \\
\text { No admixture used } \\
E_{\mathrm{g}} \\
f_{\mathrm{ck}}\end{array}$ \\
\hline Reinforcing bar & $\begin{array}{c}\text { Length }[\mathrm{m}] \\
\text { Diameter }[\mathrm{m}] \\
\text { Area }\left[\mathrm{mm}^{2}\right] \\
\text { Elastic modulus [GPa] } \\
\text { Ultimate strength [MPa] } \\
\text { Yield strength [MPa] }\end{array}$ & $\begin{array}{c}12 \\
0.075 \\
4417.9 \\
210 \\
>550 \\
>500\end{array}$ & $\begin{array}{l}\text { Pile head of } 1.5 \mathrm{~m} \text { exposed above the } \\
\text { ground surface; } L \\
D_{\text {rebar }} \\
A_{\mathrm{s}} \\
E_{\mathrm{s}} \\
f_{\mathrm{u}} \\
f_{\mathrm{y}}\end{array}$ \\
\hline Micropile & $\begin{array}{c}\text { Area [mm²] } \\
\text { Elastic modulus [GPa] }\end{array}$ & $\begin{array}{c}24,605.7 \\
62\end{array}$ & $\begin{array}{c}\text { Area of borehole, } A_{\mathrm{p}} \\
\left(A_{\mathrm{g}} E_{\mathrm{g}}+A_{\mathrm{s}} E_{\mathrm{s}}\right) /\left(A_{\mathrm{g}}+A_{\mathrm{s}}\right), E_{\text {predicted }}\end{array}$ \\
\hline
\end{tabular}

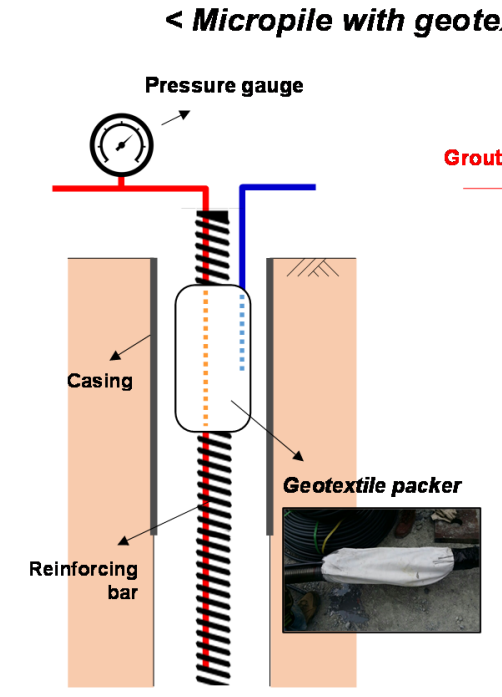

(a)

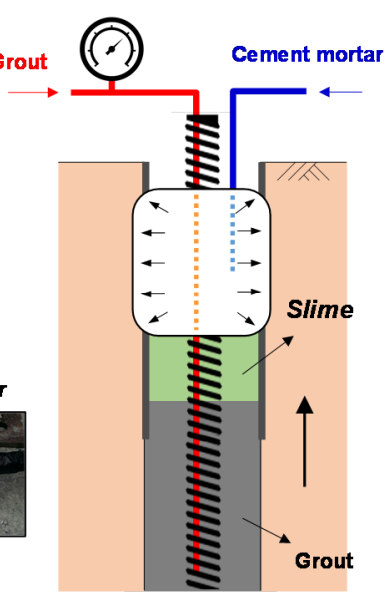

(b)

\section{<Micropile with rubber packer >}

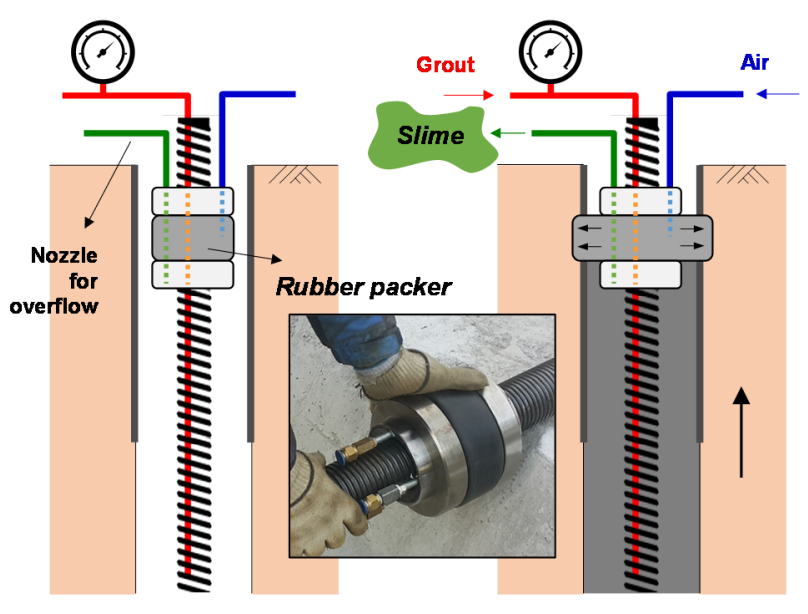

(c)

(d)

Figure 3. Construction processes of pressure-grouted micropiles using $(\mathbf{a}, \mathbf{b})$ geotextile and (c,d) rubber packers. (a) A reinforcing bar is placed into the borehole with a geotextile packer attached. (b) The geotextile packer is expanded by cement mortar; therefore, the borehole is packed. During grouting, slime is generated and transferred to the upper part of the borehole. (c) A reinforcing bar is placed in the borehole with a rubber packer attached. (d) The rubber packer is expanded using air and the borehole is filled with pure grout. In this case, slime can be discharged through a nozzle attached to the rubber packer. After the completion of grouting, the rubber packer is deflated and the packer is removed from the reinforcing bar for reuse.

The micropile using a rubber packer was installed as follows. A reinforcing bar with the rubber packer was inserted into the borehole. The rubber packer was expanded via air and grouting was induced with pressure. The rubber packer consisted of a rubber tube between two steel disks. The rubber tube was inflatable by air through a nozzle attached. The rubber packer had threads so that the rubber packer could be screwed onto the reinforcing bar (Figure 3c). Another nozzle attached to the rubber packer was to 
discharge a slime induced during grouting (Figure 3d). Furthermore, the rubber packer used can be unscrewed for reuse after the grouting is fully cured.

\subsection{Tension Load and Creep Testing}

Tension load and creep tests were conducted followed by Sabatini et al. and ASTM D3689M-07(2013)e1 [14,27] to evaluate the elastic and plastic characteristics of micropiles. During the tension load test, loads were incremented as $0,0.15,0.30,0.60,0.75,0.90,1.00$, $1.15,1.30,1.45$, and 1.60 times of the target load $(T L=1000 \mathrm{kN})$ for loading, and 1.60, $1.30,1.00,0.75,0.50,0.25$, and 0 times of $T L$ for unloading. Applied loads remained for 2.5 minutes. A tensile tester (2.75 MN max. capacity), a hydraulic pump (70 MPa), a pressure transducer (100 MPa), a linear variable differential transformer (LVDT, $200 \mathrm{~mm}$ ), a data logger (DC-105R and DC-7104R), and reference beams were used. All devices were equipped by $T M L$, Japan. The loads were applied by the tensile tester and the hydraulic pump attached to the reference beam. The LVDT was fixed to a reference beam placed at a distance at least five times the diameter of the tested micropile away. After completing the test, an unrecoverable displacement (i.e., plastic displacement, $\delta_{\mathrm{p}}$ ) was calculated by subtracting the elastic displacement $\left(\delta_{\mathrm{e}}\right)$ from total displacement $\left(\delta_{\mathrm{t}}\right)$.

A creep test was performed at $1.30 \mathrm{TL}$. The displacements at $0,1,3,4$, and 10 minutes were recorded. The creep is defined as the difference between the total displacement measured at $10 \mathrm{~min}$ and the displacement measured at $1 \mathrm{~min}$. The creep should not exceed $1 \mathrm{~mm}$ [14].

\section{Test Results}

\subsection{Tension Load Test and Elastic Characteristics}

Five micropiles installed using the gravitational grouting (denoted as $\mathrm{Gr}$ ), 3 with the geotextile packer $(G e)$, and 5 with the rubber packer $(R u)$ were tested by the tension load tests (Figure 4). Note that the testing results vary due to the spatial variability of the ground; however, it can be said that similar trends were observed within the same method. The displacement linearly increased and decreased in general, regardless of the installation methods. Davisson's analysis [28] indicated that all results are less than the ultimate settlement or bearing capacity within the given level of loads. Based on Figure 4, the results from the tension load tests were averaged within the same method for comparison, and presented in Figure 5. A higher pullout resistance was observed in an order of $R u, G e$, and $G r$. The $\delta_{\mathrm{t}}$ at $P=1600 \mathrm{kN}$ showed $6.14 \mathrm{~mm}, 9.34 \mathrm{~mm}$, and $12.26 \mathrm{~mm}$ for $R u, G e$, and $G r$, respectively.
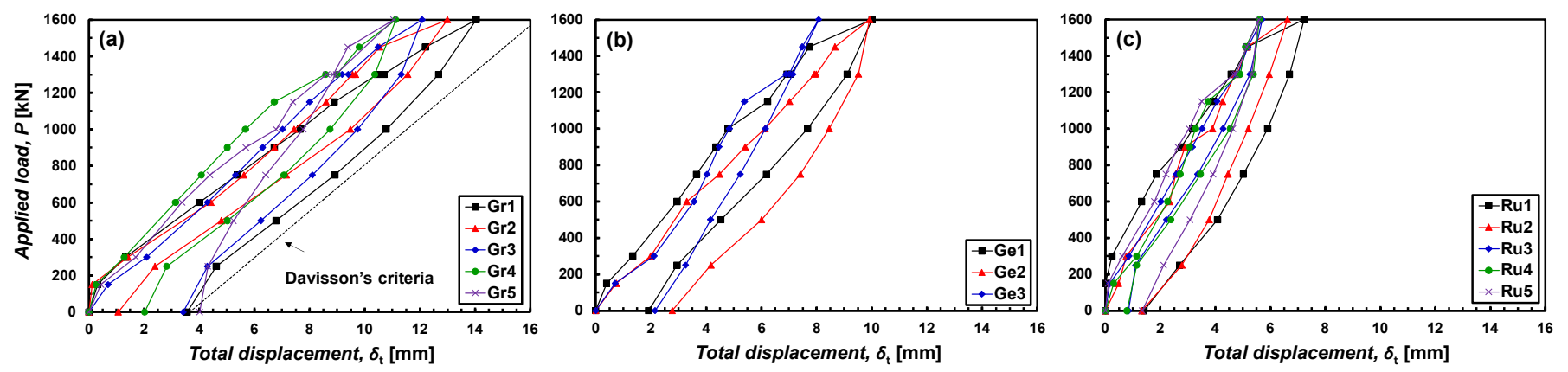

Figure 4. Results of tension load tests. (a) Micropiles installed using only gravitational grouting (Gr), (b) geotextile packer $(G e)$, and (c) rubber packer $(R u)$. 


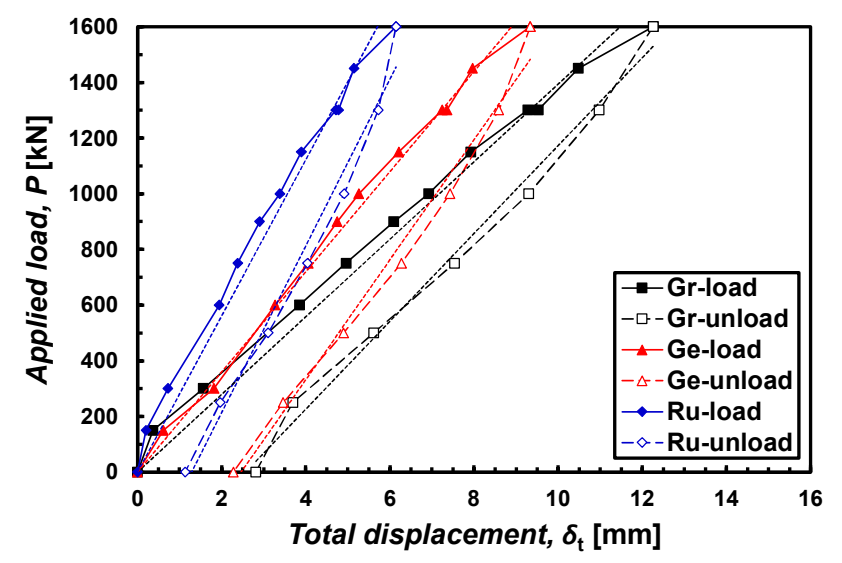

Figure 5. Comparison of pullout capacity of micropiles with different installation methods.

Assuming the behavior is elastic, the pullout modulus of the load-displacement relationship was calculated dividing the applied load by the total displacement for each loading ( $M_{\text {loading }}$ ) and unloading zone $\left(M_{\text {unloading }}\right)$. The value of $\mathrm{R}^{2}$ was found to be 0.98 0.99 , and thus, it was confirmed that the given load is within the elastic zone. The values obtained values are summarized in Table 3. For the pullout modulus during the loading cycle, $M_{\text {loading }}$ showed $280.5 \mathrm{kN} / \mathrm{mm}, 179.9 \mathrm{kN} / \mathrm{mm}$, and $139.3 \mathrm{kN} / \mathrm{mm}$ for $R u, G e$, and $G r$, respectively. As the total displacement at $P=1600 \mathrm{kN}$ was lower in an order of $R u, G e$, and $G r$, the calculated modulus was higher in an order of $R u, G e$, and $G r$. The $M_{\text {unloading, }}$ the pullout modulus during the unloading cycle, was $299.4 \mathrm{kN} / \mathrm{mm}, 215.9 \mathrm{kN} / \mathrm{mm}$, and $157.8 \mathrm{kN} / \mathrm{mm}$ for $R u, G e$, and $G r$, respectively. The $M_{\text {unloading }}$ showed a higher value than $M_{\text {loading }}$ due to stress hardening. The order of $M_{\text {unloading }}$ is same as the order of $M_{\text {loading. }}$.

Table 3. Pullout modulus of micropiles in the elastic zone.

\begin{tabular}{cccc}
\hline Type & $G r$ & $G e$ & $R \boldsymbol{u}$ \\
\hline$M_{\text {loading }}[\mathrm{kN} / \mathrm{mm}]$ & 139.3 & 179.9 & 280.5 \\
\hline$M_{\text {unloading }}[\mathrm{kN} / \mathrm{mm}]$ & 157.8 & 215.9 & 299.4 \\
\hline$E_{\text {predicted }}[\mathrm{GPa}]$ & & $62\left(D_{\text {rebar }}=75 \mathrm{~mm}\right)$ & \\
\hline$E_{\text {loading }}[\mathrm{GPa}]$ & 67.9 & 87.7 & 136.8 \\
\hline$E_{\text {unloading }}[\mathrm{GPa}]$ & 76.9 & 105.3 & 146 \\
\hline $\begin{array}{c}\text { Equivalent rebar diameter } \\
\left(D_{\text {hole }}=177 \mathrm{~mm}\right)[\mathrm{mm}]\end{array}$ & 81.3 & 100.3 & 147.6 \\
\hline
\end{tabular}

Assuming an elastic loading mechanism, the theoretical elastic modulus of the micropile was analyzed and summarized in Table 3 as well. A predicted elastic modulus ( $\left.E_{\text {predicted }}\right)$ based on the properties of the reinforcing bar and the grout was calculated as $62 \mathrm{GPa}\left(\left[A_{\mathrm{g}} E_{\mathrm{g}}+A_{\mathrm{s}} E_{\mathrm{s}}\right] /\left[A_{\mathrm{g}}+A_{\mathrm{s}}\right]\right)$. A measured elastic modulus ( $E_{\text {loading }}$ and $\left.E_{\text {unloading }}\right)$ was calculated using the applied load, area, and vertical strain (e.g., total displacement over micropile length, Table 3). The $E_{\text {loading }}$ for $G r$ was $67.9 \mathrm{GPa}$, and this was sufficiently similar to $E_{\text {predicted }}=62 \mathrm{GPa}$. The $E_{\text {loading for }}$ Ge $\left(E_{\text {loading }(\mathrm{Ge})}\right)$ gave the value of $87.7 \mathrm{GPa}$ and this value is $41.5 \%$ higher than $E_{\text {predicted. }}$. The $E_{\text {loading(Ge) }}$ was equivalent to the micropile with $D_{\text {rebar }}=100.3 \mathrm{~mm}$ with $D_{\text {hole }}=177 \mathrm{~mm}$. Given that the testing ground is fractured soft rock, it was concluded that the bonding stress between the grout and soils was effectively improved by the infiltration of the pressured grouting through the fractures in accordance with previous research [17]. The $E_{\text {loading(Ru) }}$ was calculated as $136.8 \mathrm{GPa}$, which is $221 \%$ higher than $E_{\text {predicted. }}$. The value corresponds to $D_{\text {rebar }}=147.6 \mathrm{~mm}$ with $D_{\text {hole }}=177 \mathrm{~mm}$. The $E_{\text {loading }(\mathrm{Ru})}=136.8 \mathrm{GPa}$ presented $56 \%$ higher than $E_{\text {loading }(\mathrm{Ge})}=87.7 \mathrm{GPa}$. Therefore, it 
is implied that the rubber packer has a higher packability than the geotextile packer. This will be addressed further in the Discussion section.

\subsection{Creep Test and Plastic Characteristics}

The creep tests were implemented under $P=1300 \mathrm{kN}$ at loading phase and displacements $(\Delta \delta)$ were recorded (Figure 6). It has been shown that when the displacement is below $1 \mathrm{~mm}$ for 10 minutes under $1.3 \mathrm{TL}$, the micropile is stable against a creep [14]. As shown in Figure 6, all creep displacements were less than $1 \mathrm{~mm}$, so the micropiles installed were acceptable; however, the variation in creep was shown to be different according to the installation methods. For $G r$, the slopes of the creep displacement gradually decreased as time passed. On the other hand, $G e$ and $R u$ were shown to be roughly consistent after approximately 3-5 min creep testing, which implies faster stabilization on creep than $G r$.
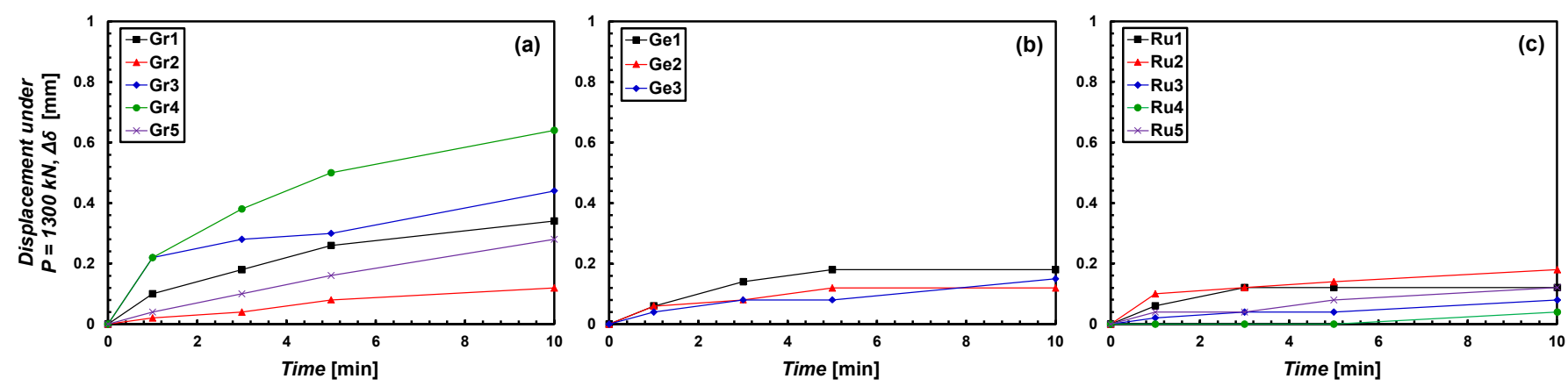

Figure 6. Results of creep tests. (a) Micropiles installed using only gravitational grouting (Gr), (b) geotextile packer (Ge), and $(\mathbf{c})$ rubber packer $(R u)$.

The magnitudes of the creep displacements $\left(\delta_{\text {creep }}\right)$ are summarized in Table 4 in addition to the magnitudes of the plastic displacement after completing the unloading cycle (i.e., plastic displacement, $\delta_{\mathrm{p}}=\delta_{\mathrm{t}}-\delta_{\mathrm{e}}$ ). The $\delta_{\text {creep }}$ for $G r$ is 2.2 and 4 times higher than those for Ge and $R u$, respectively. Besides, the standard deviations of $\delta_{\text {creep }}$ showed the fluctuation of the displacement as $\sigma_{\text {creep }(\mathrm{Gr})}=0.10 \mathrm{~mm}, \sigma_{\text {creep }(\mathrm{Ge})}=0.03 \mathrm{~mm}$, and $\sigma_{\text {creep }(\mathrm{Ru})}=0.01 \mathrm{~mm}$. The magnitudes of the creep displacements and corresponding standard deviations indicated more stable bonding between the micropile and soil in an order of $R u, G e$, and $G r$. The trend of $\delta_{\mathrm{p}}$ and $\sigma_{\text {plastic }}$ showed a similar trend with $\delta_{\text {creep }}$ and $\sigma_{\text {creep }}$, but they were slightly different. The average $\delta_{\mathrm{p}(\mathrm{Gr})}$ and $\delta_{\mathrm{p}(\mathrm{Ge})}$ was shown to be similar at $2.8 \mathrm{~mm}$ and $2.3 \mathrm{~mm}$ respectively, while $\delta_{\mathrm{p}(\mathrm{Ru})}$ was $1.1 \mathrm{~mm}$. The $\sigma_{\text {plastic }}$ of $G r$ was $1.10 \mathrm{~mm}$, while $G e$ and $R u$ were shown to be similar at $0.36 \mathrm{~mm}$ and $0.27 \mathrm{~mm}$, respectively.

Table 4. Creep and plastic displacements.

\begin{tabular}{cccc}
\hline Type & $G r$ & $G e$ & $R \boldsymbol{u}$ \\
\hline$\delta_{\text {creep }}$ (average) $[\mathrm{mm}]$ & $0.1,0.22,0.24,0.24,0.42$ & $0.07,0.12,0.13(0.11)$ & $0.04,0.06,0.06,0.08,0.08$ \\
$\delta_{\mathrm{p}}$ (average) $[\mathrm{mm}]$ & $(0.24)$ & $1.9,2.1,2.8(2.3)$ & $0.8,0.8,1.3,1.3,1.4(1.1)$ \\
$\sigma_{\text {creep }}[\mathrm{mm}]$ & 0.10 & 0.03 & 0.01 \\
$\sigma_{\mathrm{p}}[\mathrm{mm}]$ & 1.10 & 0.36 & 0.27 \\
\hline
\end{tabular}

The variations in creep and plastic displacements would include the spatial variability of the ground; however, there seem to be clear trends according to the different installation methods. The pressure-grouted micropiles using the geotextile and rubber packers showed superior plastic characteristics than the one using gravitational grouting. Even the rubber packer may eliminate the uncertainties resulting from the geological and installationrelated issues. 


\section{Discussion}

\subsection{Efficiency of Pressure Grouting on Fractured Zone}

Experimental results demonstrated the superiority of pressure-grouted micropiles to gravitationally grouted ones. The benefits of using pressure grouting are magnified when the micropiles should be installed in ground with fractured zones. The pressure grouting in week zones plays the same role as fracture grouting to fill the gaps in the ground [29]. Fracture grouting is a technique to inject fluid grouting (e.g., cement slurry) with pressure into the ground to address fractures in the ground. As the pressure grouting is injected into the ground, grout lenses are generated horizontally in weak areas [30]. These grout lenses provide considerable support to the bearing capacity and pullout capacity of the micropile. This mechanism is illustrated in Figure 7. The pressure grouting infiltrates into the fractured zones, forming grout lenses in weak spots. The fractured rocks have a very low strength, but the fractured ground bonded with pressure grouting has a high strength, equivalent to that of intact rock. In addition, the bonding strength between soil and grout is improved. Thus, micropiles are an effective alternative when deep foundation systems cannot be used because of the presence of a hard layer, and there is uncertainty regarding the extent of the fractured zone. The pressure-grouted micropile not only ensures a better stress-strain relationship (Figure 5), but also overcomes the geological uncertainties (Table 4).

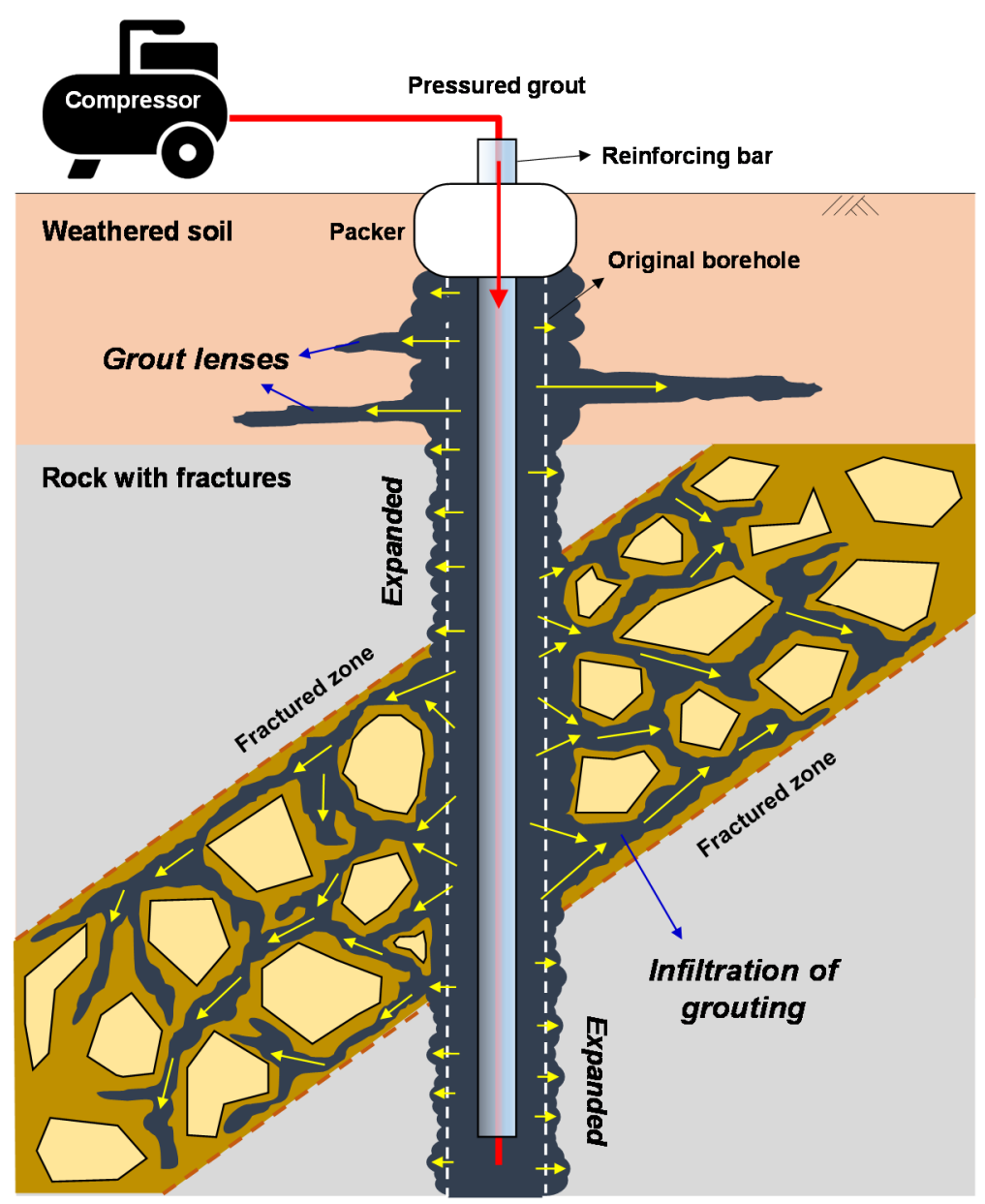

Figure 7. Micropile with pressure grouting in fractured zone.

\subsection{Superior Performance of Rubber Packer Than Geotextile Packer}

It was anticipated that when pressure is applied to grouting after packing the borehole using the packer, the entire pressure is transferred into the borehole. However, the experimental results showed that there was a different pullout capacity and creep behavior of the pressure-grouted micropiles installed using the geotextile packer and the rubber 
packer (Figure 5). This can be attributed to the limitations of the geotextile packer and the superior performance of the rubber packer. The geotextile packer is manually tightened on the reinforcing bar close to the entrance of the borehole (Figure 3a). Then, the packing of the borehole takes place as the packer expands by injecting cement slurry. However, there are practical problems with incomplete packing of the borehole. In this experiment, it was observed that the pressure grouting frequently leaked between the geotextile packer and the reinforcing bar, or the geotextile packer and the casing during grout filling. The leakage stopped when the internal pressure was dissipated. The level of leakage was highly dependent on the packability of the packer. The packability (i.e., manual tightening) varied depending on the practitioner's level of proficiency.

The micropile installed using the rubber packer showed marginal leakage or no leakages during pressure grouting. The rubber packer seemed to bring a tight contact with the reinforcing bar and the casing after expanding with air. Consequently, the applied pressure was maintained during pressure grouting, which induces higher bonding stress between the micropile and soils. In addition, the rubber packer enabled us to eliminate the slime that is transferred to the top of the borehole during grouting via the nozzle attached on the packer (Figure 3d). Although the presence of the slime was not exactly evaluated in this study, purer grouting in the borehole should lead to higher bonding stress. The use of the nozzle should be investigated further.

\section{Conclusions}

Pressure-grouted micropiles installed using gravitational grouting, a geotextile packer, and a rubber packer were evaluated via tension load and creep tests. A site affected by groundwater and with a fractured zone was selected for the field tests. The stress-strain relationship of the pressure-grouted micropiles showed a higher pullout capacity than micropiles installed using gravitational grouting. The magnitude of creep and plastic displacements showed the same trend. Of the three methods, the micropiles installed using the rubber packer presented superior performances, which resulted from the packability of the rubber packer. Based on this case and comparative studies, the pressure-grouted micropile can be considered the most effective foundation system in areas affected by water tables and fracture zones. However, physical evidence showing the packability of pressure-grouted micropiles needs to be revealed in future research.

Author Contributions: Conceptualization, O.H. and Y.Y.; methodology, O.H. and Y.Y.; formal analysis, J.D.; O.H. and J.D.; writing—original draft preparation, J.D.; writing—review and editing, J.D.; funding acquisition, J.D. All authors have read and agreed to the published version of the manuscript.

Funding: Funding from Gyeongsang National University Office of Academy and Industry Collaboration and Marine Industry Research Center is appreciated.

Data Availability Statement: Some or all data, models, or code that support the findings of this study are available from the corresponding author upon reasonable request.

Conflicts of Interest: The authors declare no conflict of interest.

\section{References}

1. Daniel, D.E. Geotechnical Practice for Waste Disposal; Springer Science \& Business Media: Berlin, Germany, 1993.

2. Hekmatzadeh, A.A.; Zarei, F.; Johari, A.; Haghighi, A.T. Reliability analysis of stability against piping and sliding in diversion dams, considering four cutoff wall configurations. Comput. Geotech. 2018, 98, 217-231. [CrossRef]

3. Rao, K.S.S.; Venkatesh, K.H. Uplift Behaviour of Short Piles in Uniform Sand. Soils Found. 1985, 25, 1-7. [CrossRef]

4. Bowles, L.E. Foundation Analysis and Design; McGraw-Hill Education: New York, NY, USA, 1996.

5. Bailey, H.; Senior, B.; Simmons, D.; Rusin, J.; Picken, G.; Thompson, P.M. Assessing underwater noise levels during pile-driving at an offshore windfarm and its potential effects on marine mammals. Mar. Pollut. Bull. 2010, 60, 888-897. [CrossRef]

6. Bruce, D.A.; Juran, I. Drilled and Grouted Micropiles: State-of-Practice Review: Volume 2. Design; US Federal Highway Administration: Washington, DC, USA, 1997.

7. Armour, T.; Groneck, P.; Keeley, J.; Sharma, S. Micropile Design and Construction Guidelines: Implementation Manual; US Federal Highway Administration: Washington, DC, USA, 2000. 
8. Misra, A.; Chen, C.H. Analytical solution for micropile design under tension and compression. Geotech. Geol. Eng. 2004, 22, 199-225. [CrossRef]

9. Misra, A.; Chen, C.H.; Oberoi, R.; Kleiber, A. Simplified analysis method for micropile pullout behavior. J. Geotech. Geoenviron. Eng. 2004, 130, 1024-1033. [CrossRef]

10. Pearlman, S.L.; Wolosick, J.R. Pin piles for bridge foundations. In Proceedings of the 9th Annual International Bridge Conference, Pittsburgh, PA, USA, 10-12 June 1992.

11. Bruce, D.A.; Gemme, R. Current practice in structural underpinning using pinpiles. In Proceedings of the New York Met Section, ASCE Seminar, New York, NY, USA, 21-22 April 1992.

12. Bivens, M.J.; Siegel, T.C. Case histories of micropile in karst: The influence of installation on design and performance. In Contemporary Issues in Deep Foundations; ASCE: Reston, VA, USA, 2007; pp. 1-8.

13. Gibler, P.; Bruce, D.A.; Hadzariga, M. Quality assurance issues related to the installation of high capacity micropiles, RichmondSan Rafael bridge seismic retrofit project, California. In Proceedings of the Geo3 Conference on Geo Construction Quality Assurance/Quality Control, Dallas, TX, USA, 6-9 November 2005; pp. 6-9.

14. Sabatini, P.J.; Armour, T.; Groneck, P.; Keeley, J.W.; Tanyu, B. Micropile Design and Construction (Reference Manual for NHI Course 132078) (No. FHWA-NHI-05-039); US Federal Highway Administration: Washington, DC, USA, 2005.

15. Schleiss, A.J. Design of pervious pressure tunnels. Water Power Dam Constr. 1986, 38, 21-26.

16. Kasper, T.; Meschke, G. On the influence of face pressure, grouting pressure and TBM design in soft ground tunneling. Tunn. Undergr. Space Technol. 2006, 21, 160-171.

17. Yin, J.H.; Su, L.J.; Cheung, R.W.M.; Shiu, Y.K.; Tang, C. The influence of grouting pressure on the pullout resistance of soil nails in compacted completely decomposed granite fill. Geotechnique 2009, 59, 103-113. [CrossRef]

18. Amadei, B. 37th US Symposium on Rock Mechanics (Vol. 2); Taylor \& Francis, England: Abingdon, UK, 1999.

19. Schmitt, A. Rock versus porous mass concrete, drilling, scanning, water pressure-and grouting-tests. In Proceedings of the ISRM International Symposium-EUROCK 2012, Stockholm, Sweden, 28 May 2012.

20. Saito, K.; Maekawa, K.; Tamura, M.; Fujii, M.; Sugimura, Y.; Nomura, H. Investigation of Slime and Slurry in Cast-in-Place Concrete Piles by Resistivity Method. Soils Found. 1999, 39, 117-123. [CrossRef]

21. Chun, O.H.; Yoon, H.K.; Park, M.C.; Lee, J.S. Slime thickness evaluation of bored piles by electrical resistivity probe. J. Appl. Geophys. 2014, 108, 167-175. [CrossRef]

22. Heo, O. Setting Anchoring-Bolts with Provisions for Grouting. Korea Patent KR101725330B1, 10 September 2017.

23. American Society for Testing and Materials. Standard Practice for Classification of Soils for Engineering Purposes (Unified Soil Classification System); ASTM D2487-17e1; American Society for Testing and Materials: West Conshohocken, PA, USA, 2017.

24. Mayo, R.E.; Glondys, N.B.; Mayo, D.P. 100-Ton (890 kN) Rock anchor Pullout Test. Pract. Period. Struct. Des. Constr. 2003, 8, 31-35.

25. Sew, I.D.G.S.; Chin, I.T.Y.; Shong, I.L.S. A brief guide to design of bored piles under axial compression-A Malaysian approach. In Proceedings of the In Seminar and Exhibition on Bridge Engineering, Kulala Lumpur, Malaysia, February 2003 ; pp. 8-22.

26. Jinrong, D. Influence of pile bottom slime on skin friction and bearing capacity estimation to pile. Ind. Constr. $2009,39,93-97$.

27. American Society for Testing and Materials. Standard Test Methods for Deep Foundations under Static Axial Tensile Load; ASTM D3689M-07(2013)e1; American Society for Testing and Materials: West Conshohocken, PA, USA, 2013.

28. Davisson, M.T. High capacity piles. In Proceedings of the Soil Mechanics Lecture Series on Innovations in Foundation Construction, Chicago, IL, USA, 1 March 1972; pp. 81-112.

29. Wong, H.Y.; Farmer, I.W. Hydrofracture mechanisms in rock during pressure grouting. Rock Mech. 1973, 5, 21-41. [CrossRef]

30. Warner, J. Practical Handbook of Grouting—Soil, Rock and Structures; Wiley: Hoboken, NJ, USA, 2004. 